\title{
Goosefoot - a plant that likes drought. The goosefoot family pollen season in 2019 in Poland, Hungary and Slovakia
}

\author{
Małgorzata Puc ${ }^{1,2}$, Piotr Rapiejko ${ }^{3,4}$, Donát Magyar5, Orsolya Udvardy5, Jana Ščevková ${ }^{6}$, Janka Lafférsová7, \\ Tomasz Wolski', Krystyna Piotrowska-Weryszko ${ }^{8}$, Małgorzata Malkiewicz ${ }^{9}$, Grzegorz Siergiejko ${ }^{10}$, \\ Katarzyna Dąbrowska-Zapart"11, Monika Ziemianin ${ }^{12}$, Ewa Kalinowska ${ }^{4}$, Kornel Szczygielski³ \\ Andrzej Wieczorkiewicz ${ }^{4}$, Agnieszka Lipiec ${ }^{13}$ \\ ${ }^{1}$ Institute of Marine \& Environmental Sciences, University of Szczecin, Szczecin, Poland \\ ${ }^{2}$ Molecular Biology and Biotechnology Centre, Faculty of Biology, University of Szczecin, Poland \\ ${ }^{3}$ Department of Otolaryngology with Division of Cranio-Maxillo-Facial Surgery in Military Institute of Medicine, \\ Warsaw, Poland \\ ${ }^{4}$ Allergen Research Center, Warsaw, Poland \\ ${ }^{5}$ National Public Health Center, Hungarian Aerobiological Network, Budapest, Hungary \\ ${ }^{6}$ Faculty of Natural Sciences, Department of Botany, Comenius University in Bratislava, Bratislava, Slovakia \\ ${ }^{7}$ Public Health Office, Department of Environmental Biology, Banská Bystrica, Slovakia \\ ${ }^{8}$ Department of Botany and Plant Physiology, University of Life Sciences in Lublin, Poland \\ ${ }^{9}$ Laboratory of Paleobotany, Department of Stratigraphical Geology, Institute of Geological Sciences, \\ University of Wroclaw, Wroclaw, Poland \\ 10 Pediatrics, Gastroenterology and Allergology Department, University Children's Hospital, \\ Medical University of Bialystok, Poland \\ ${ }^{11}$ Faculty of Natural Sciences, Institute of Earth Sciences, University of Silesia in Katowice, Poland \\ ${ }^{12}$ Department of Clinical and Environmental Allergology, Medical College, Jagiellonian University, Cracow, Poland \\ ${ }^{13}$ Department of Prevention of Environmental Hazards and Allergology, Medical University of Warsaw, Poland
}

\begin{abstract}
:
Almost all the species of the Chenopodiaceae family present in our flora flower from July-August to the autumn. Unfortunately, allergies do not take a vacation. Warm, dry July and August weather should limit pollen emissions. However, similarly to most plants in dry habitats, goosefoot are well adapted to such conditions and does not provide even a short reprieve to pollen allergic patients. However, goosefoot pollen does not have a very large allergenic significance; despite the long pollen season lasting about 3 months, pollen concentrations in the air are low and very rarely exceed the concentration of 30 grains $/ \mathrm{m}^{3}$. This study compares Chenopodiaceae pollen seasons in Poland, Hungary and Slovakia in 2019. The investigations were carried out using the volumetric method (Hirst type pollen sampler). Seasonal pollen index was estimated as the sum of daily average pollen concentrations in the given season. The pollen season ranges from June to September, depending on the geographical latitude. In Hungary and Slovakia there are much longer pollen seasons than in Poland. Pollen of goosefoot family contains the panallergen profilins, which are responsible for cross-reactivity among pollen-sensitized patients. In 2019 the pollen season of goosefoot started first in Hungary, in Kaposvar on June $7^{\text {th }}$ and in Slovakia, in Žilina, on June $8^{\text {th; }}$ in Poland pollen season started much later, on June $14^{\text {th }}$ in Szczecin and Opole. At the latest, a pollen season ended in Nitria (Slovakia) on October $16^{\text {th; }}$; in Kecskemet (Hungary) on October $3^{\text {rd }}$. In Poland the season ended much earlier than in Hungary and Slovakia already on August $25^{\text {th }}$. The differences of pollen season durations are considerable, the number of days ranged from 72 to 128. The dynamics of the pollen seasons of goosefoot family show similarities within a given country and considerable differences between these countries. However, the differences of the highest airborne concentration between the countries are not considerable ( 25 pollen grains $/ \mathrm{m}^{3}$ in Poland, 49 pollen grains $/ \mathrm{m}^{3}$ in Hungary, and 30 pollen grains $/ \mathrm{m}^{3}$ in Slovakia. The maximum values of seasonal pollen count in Polish cities occurred between July $26^{\text {th }}$ and August $29^{\text {th }}$, in Hungarian cities between August $27^{\text {th }}$ and $30^{\text {th }}$, and in Slovakian cities between August $7^{\text {th }}$ and
\end{abstract}


28 $8^{\text {th }}$. Pollen season was characterized by extremely different total annual pollen SPI, in Poland from 116 to 360; in Hungary and Slovakia within the limits 290 to 980 . Droughts that occur more frequently during the summer facilitate the spread of species of the goosefoot family due to the possibility of these plants gaining new habitats.

Key words: aeroallergens, pollen count, goosefoot family (Chenopodiaceae), Amaranthaceae, 2019, Poland, Hungary, Slovakia

\section{Introduction}

Summer activities should be enjoyed outside, reaping the benefits of the warm months. However, hot summers being noted more and more often combined with heightened allergies make an undesirable recipe. Herbaceous plants allergies are at their peak during the summer months. They produce allergenic pollens that trigger some of the most aggravating allergy symptoms.

The most important agent causing pollinosis in Europe is herbaceous pollen. Goosefoot pollen can induce asthma, allergic rhinitis and allergic conjunctivitis. Chenopodiaceae like other herbaceous plants contains the panallergen profilins and polcalcins and also calcium-binding proteins, which are responsible for extensive cross-reactivity among pollen-sensitized patients [1]. Cross reactions with allergens of: Atriplex latifolia, Salsola kali and Amaranthus retroflexus were also observed [2]. Four major families of proteins seem to be the major cause of allergic reactions to weed pollen: ragweed, mugwort and probably also sunflower, plantain and goosefoot [1]. Cross-reactivity between glack locust tree (Robinia pseudoacacia) pollen and goosefoot has been demonstrated [3]. However, Chenopodiaceae pollen does not have a very large allergenic significance [2].

The Chenopodiaceae is one of those families that show only slight variation in their pollen morphology, and, despite attempts at more precise identifications of their pollen [4], only identification at the family level seems to be possible. The pollen of Amaranthaceae, very similar in respect of their morphology, is also included in this type. The flowers are inconspicuous: green, and without petals. These flowers are found in dense clusters at the tips of branches and at the top of the stem. Goosefoot flowers throughout the summer but predominantly in the autumn, producing abundant pollen. A full-grown plant can give off as many as 20,000 pollen grains.

In Europe the goosefoot family includes more than 30 genera and 150 native species, with many of them being widespread on this continent. However, the majority of species has the northern boundaries of their continuous ranges reaching no farther than southern Scandinavia. Many Chenopodiaceae species are characteristic components of the anthropogenic vegetation both as ruderals and as agricultural weeds. Cultivated species also belong to the Chenopodiaceae family, primarily belong also, first of all beetroot and spinach, and also a number of garden plants [5], hence the cross-reactivity of goosefoot family pollen with some vegetables is possible [1].

The most common species of Chenopodiaceae family are pioneer plants occurring on bare soils on open sites. Under natural conditions they occupy riverbanks, steep broken slopes and other areas in which soil disturbance and destruction of vegetation have occurred. They can grow under a wide range of soil conditions, from sand and gravel, to clay soils; they are also very tolerant to drought. Where other species are receding due to drought, goosefoot grains new habitats and spreads unhindered. They very frequently occur on cultivated ground, particularly amongst root crops and as garden weeds. Their demographic success is guaranteed by high production of seeds, which maintain their viability for several years [5].

Almost all the species of Chenopodiaceae family present in our flora flower from July-August to autumn. The symptoms of allergic disease are connected with the concentration of aeroallergens, however goosefoot pollen does not disperse very effectively and the most common genus Chenopodi$u m L$. is a relatively weak pollen producer. According to Huntley and Birks [6] values $>1 \%$ of Chenopodiaceae pollen in pollen assemblages indicate their local presence, whereas values $>5 \%$ show their abundance in the surrounding vegetation.

\section{Aim}

The aim of the study was to compare the goosefoot pollen concentrations in the air of Poland, 
Hungary and Slovakia in 2019 as well as to indicate the highest risk of pollen allergens in individual cities.

\section{Material and method}

Measurements of bioaerosol were carried out in the selected cities of Poland, Hungary and Slovakia in 2019. Measurements were performed by the volumetric method. The used devices, which are recommended by the International Association for Aerobiology (IAA), take air samples (Burkard and Lanzoni as the Hirst type pollen sampler) in volumes corresponding to average human respiratory parameters [7].

The duration of the pollen season was determined by the $98 \%$ method [8], assuming that the onset and end of the season were days with recorded $1 \%$ and $99 \%$ of the annual total of pollen grains, respectively. The total pollen count over this period was expressed by the seasonal pollen index (SPI).

In additional, the number of days was determined in which concentrations of pollen of the goose- foot exceeded the values 10 grains $/ \mathrm{m}^{3}$ and 20 grains $/ \mathrm{m}^{3}$, for which exposure to allergy symptoms increases accordingly (tab. 1-3).

\section{Results and discussion}

In Europe the herbaceous species of goosefoot family flowers from June to September. In Switzerland the SPI for these taxa is rather low and they play a minor role as allergy producers. However, in the years with hot, dry summers the SPI of Chenopodiaceae and Plantago is higher than normal [9]. According to their ecological habitats, Plantago and Chenopodiaceae are more tolerant to drought than the other species. Similar properties of the pollen season of these taxa were noted in Szczecin in the years 2004-2008 [10]. This is confirmed also by the data from the pollen season 2017 (Szczecin), when during a cool summer with high rainfall, SPI was only 86 , and the seasonal maximum only -8 grains $/ \mathrm{m}^{3}$; while in 2018 , when the summer was hot and dry, the SPI in Szczecin reached a value of 283 and

Table 1. Characteristics of goosefoot pollen season in Poland in 2019.

\begin{tabular}{|c|c|c|c|c|c|}
\hline $\begin{array}{l}\text { Features of pollen season/city (number } \\
\text { of residents in the thousands) }\end{array}$ & $\begin{array}{l}\text { Duration of pollen sea- } \\
\text { son (number of days) }\end{array}$ & $\begin{array}{l}\text { Seasonal pollen } \\
\text { index (total) }\end{array}$ & $\begin{array}{l}\text { Peak value } \\
\text { and peak date }\end{array}$ & $\begin{array}{l}\text { Days } \\
\geq 9 \text { grains } / \mathrm{m}^{3}\end{array}$ & $\begin{array}{l}\text { Days } \\
\geq 20 \text { grains } / \mathrm{m}^{3}\end{array}$ \\
\hline $\begin{array}{c}\text { Bialystok } \\
297.3\end{array}$ & $\begin{array}{c}2 \mathrm{VII}-13 \mathrm{IX} \\
72\end{array}$ & 172 & $\begin{array}{c}11 \\
31 \mathrm{VII}\end{array}$ & 1 & 0 \\
\hline $\begin{array}{c}\text { Bydgoszcz } \\
352.3\end{array}$ & $\begin{array}{l}27 \mathrm{VI}-19 \mathrm{IX} \\
85\end{array}$ & 282 & $\begin{array}{c}11 \\
2,28 \mathrm{VIII}\end{array}$ & 2 & 0 \\
\hline $\begin{array}{l}\text { Cracow } \\
774.4\end{array}$ & $\begin{array}{l}21 \text { VI-8 IX } \\
80\end{array}$ & 116 & $\begin{array}{c}7 \\
20 \mathrm{VIII}\end{array}$ & 0 & 0 \\
\hline $\begin{array}{l}\text { Sosnowiec } \\
204.5\end{array}$ & $\begin{array}{l}18 \mathrm{VI}-13 \mathrm{IX} \\
92\end{array}$ & 181 & $\begin{array}{c}7 \\
15 \mathrm{VIII}\end{array}$ & 0 & 0 \\
\hline $\begin{array}{l}\text { Lublin } \\
342\end{array}$ & $\begin{array}{c}15 \text { VI-2 IX } \\
97\end{array}$ & 359 & $\begin{array}{c}14 \\
27 \mathrm{VIII}\end{array}$ & 4 & 0 \\
\hline $\begin{array}{l}\text { Olsztyn } \\
607.5\end{array}$ & $\begin{array}{c}18 \mathrm{VI}-25 \mathrm{IX} \\
\mathbf{1 0 0}\end{array}$ & 312 & $\begin{array}{c}26 \\
29 \mathrm{VIII}\end{array}$ & 5 & 2 \\
\hline $\begin{array}{l}\text { Opole } \\
128.2\end{array}$ & $\begin{array}{c}14 \mathrm{VI}-18 \mathrm{IX} \\
97\end{array}$ & 338 & $\begin{array}{c}13 \\
11 \mathrm{VIII}\end{array}$ & 4 & 0 \\
\hline $\begin{array}{c}\text { Piotrkow Trybunalski } \\
72.2\end{array}$ & $\begin{array}{l}22 \mathrm{VI}-12 \mathrm{IX} \\
83\end{array}$ & 299 & $\begin{array}{c}9 \\
26 \mathrm{VII}, 9 \mathrm{VIII}\end{array}$ & 2 & 0 \\
\hline $\begin{array}{l}\text { Szczecin } \\
403.8\end{array}$ & $\begin{array}{l}14 \text { VI-8 IX } \\
87\end{array}$ & 233 & $\begin{array}{c}9 \\
11,18 \mathrm{VIII}\end{array}$ & 2 & 0 \\
\hline $\begin{array}{l}\text { Warsaw } \\
1764.6\end{array}$ & $\begin{array}{c}16 \mathrm{VI}-13 \mathrm{IX} \\
90\end{array}$ & 277 & $\begin{array}{c}10 \\
27 \mathrm{VIII}\end{array}$ & 1 & 0 \\
\hline $\begin{array}{l}\text { Wroclaw } \\
639.2\end{array}$ & $\begin{array}{l}19 \mathrm{VI}-19 \mathrm{IX} \\
93\end{array}$ & 211 & $\begin{array}{c}11 \\
10 \mathrm{VIII}\end{array}$ & 1 & 0 \\
\hline $\begin{array}{c}\text { Zielona Gora } \\
139.1\end{array}$ & $\begin{array}{l}18 \mathrm{VI}-21 \mathrm{IX} \\
96\end{array}$ & 315 & $\begin{array}{c}9 \\
27 \mathrm{VIII}\end{array}$ & 0 & 0 \\
\hline
\end{tabular}


Table 2. Characteristics of goosefoot pollen season in Hungary in 2019.

\begin{tabular}{|c|c|c|c|c|c|}
\hline $\begin{array}{l}\text { Features of pollen season/city (number } \\
\text { of residents in the thousands) }\end{array}$ & $\begin{array}{l}\text { Duration of pollen sea- } \\
\text { son (number of days) }\end{array}$ & $\begin{array}{l}\text { Seasonal pollen } \\
\text { index (total) }\end{array}$ & $\begin{array}{l}\text { Peak value } \\
\text { and peak date }\end{array}$ & $\begin{array}{l}\text { Days } \\
\geq 9 \text { grains } / \mathrm{m}^{3}\end{array}$ & $\begin{array}{c}\text { Days } \\
\geq 20 \text { grains } / \mathrm{m}^{3}\end{array}$ \\
\hline $\begin{array}{c}\text { Budapest } \\
1794.7\end{array}$ & $\begin{array}{c}19 \text { VI-29 IX } \\
103\end{array}$ & 718 & $\begin{array}{c}41 \\
29 \mathrm{VIII}\end{array}$ & 27 & 8 \\
\hline $\begin{array}{l}\text { Debrecen } \\
208.2\end{array}$ & $\begin{array}{l}13 \mathrm{VI}-30 \mathrm{IX} \\
110\end{array}$ & 974 & $\begin{array}{c}48 \\
29 \mathrm{VIII}\end{array}$ & 9 & 15 \\
\hline $\begin{array}{l}\text { Gyor } \\
131.3\end{array}$ & $\begin{array}{l}12 \mathrm{VI}-28 \mathrm{IX} \\
109\end{array}$ & 379 & $\begin{array}{c}14 \\
27 \mathrm{VIII}\end{array}$ & 12 & 0 \\
\hline $\begin{array}{c}\text { Kaposvar } \\
68.0\end{array}$ & $\begin{array}{c}7 \mathrm{VI}-1 \mathrm{X} \\
117\end{array}$ & 344 & $\begin{array}{c}26 \\
2 I X\end{array}$ & 11 & 1 \\
\hline $\begin{array}{c}\text { Kecskemét } \\
113.3\end{array}$ & $\begin{array}{l}20 \text { VI-3 X } \\
106\end{array}$ & 902 & $\begin{array}{c}45 \\
29 \mathrm{VIII}\end{array}$ & 34 & 12 \\
\hline $\begin{array}{c}\text { Miskolc } \\
160.0\end{array}$ & $\begin{array}{l}11 \mathrm{VI}-17 \mathrm{IX} \\
99\end{array}$ & 284 & $\begin{array}{c}18 \\
11 \mathrm{VIII}, \\
29 \mathrm{VIII}\end{array}$ & 8 & 0 \\
\hline $\begin{array}{l}\text { Nyíregyháza } \\
117.8\end{array}$ & $\begin{array}{c}18 \mathrm{VI}-1 \mathrm{X} \\
106\end{array}$ & 933 & $\begin{array}{c}30 \\
1 \mathrm{VIII}\end{array}$ & 41 & 12 \\
\hline $\begin{array}{l}\text { Pecs } \\
147.7\end{array}$ & $\begin{array}{c}9 \mathrm{VI}-29 \mathrm{IX} \\
113\end{array}$ & 339 & $\begin{array}{c}24 \\
29 \mathrm{VIII}\end{array}$ & 9 & 1 \\
\hline $\begin{array}{c}\text { Siofok } \\
25.5\end{array}$ & $\begin{array}{l}4 \mathrm{VII}-30 \mathrm{IX} \\
83\end{array}$ & 576 & $\begin{array}{c}49 \\
28 \mathrm{VIII}\end{array}$ & 18 & 7 \\
\hline
\end{tabular}

Table 3. Characteristics of goosefoot pollen season in Slovakia in 2019.

\begin{tabular}{|c|c|c|c|c|c|}
\hline $\begin{array}{l}\text { Features of pollen season/city (number } \\
\text { of residents in the thousands) }\end{array}$ & $\begin{array}{l}\text { Duration of pollen sea- } \\
\text { son (number of days) }\end{array}$ & $\begin{array}{l}\text { Seasonal pollen } \\
\text { index (total) }\end{array}$ & $\begin{array}{l}\text { Peak value } \\
\text { and peak date }\end{array}$ & $\begin{array}{l}\text { Days } \\
\geq 9 \text { grains } / \mathrm{m}^{3}\end{array}$ & $\begin{array}{l}\text { Days } \\
\geq 20 \text { grains } / \mathrm{m}^{3}\end{array}$ \\
\hline $\begin{array}{c}\text { Bratislava } \\
424.4\end{array}$ & $\begin{array}{l}19 \mathrm{VI}-1 \mathrm{X} \\
105\end{array}$ & 370 & $\begin{array}{c}15 \\
28 \mathrm{VIII}\end{array}$ & 10 & 0 \\
\hline $\begin{array}{c}\text { Banská Bystrica } \\
78.7\end{array}$ & $\begin{array}{c}28 \mathrm{VI}-24 \mathrm{IX} \\
89\end{array}$ & 293 & $\begin{array}{c}22 \\
27 \mathrm{VIII}\end{array}$ & 10 & 1 \\
\hline $\begin{array}{l}\text { Nitra } \\
77.6\end{array}$ & $\begin{array}{l}13 \mathrm{VI}-16 \mathrm{X} \\
126\end{array}$ & 983 & $\begin{array}{c}30 \\
7 \mathrm{VIII}\end{array}$ & 43 & 10 \\
\hline $\begin{array}{c}\text { Trnava } \\
65.5\end{array}$ & $\begin{array}{l}25 \mathrm{VI}-28 \mathrm{IX} \\
92\end{array}$ & 321 & $\begin{array}{c}22 \\
21 \mathrm{VIII}\end{array}$ & 12 & 2 \\
\hline $\begin{array}{c}\text { Žilina } \\
81.0\end{array}$ & $\begin{array}{c}8 \mathrm{VI}-13 \mathrm{X} \\
128\end{array}$ & 522 & $\begin{array}{c}21 \\
23 \mathrm{VIII}\end{array}$ & 16 & 1 \\
\hline
\end{tabular}

in the same year the seasonal maximum 14 grains $/ \mathrm{m}^{3}$; in Wroclaw the value of SPI was 652 and the seasonal maximum 124 grains $/ \mathrm{m}^{3}$.

Goosefoot family pollen stays in the air for a very long time. In 2018, in Poland [11] goosefoot pollen appeared in the air between May $30^{\text {th }}$ and June $5^{\text {th }}$. The last grains of Chenopodiaceae were found between September $18^{\text {th }}$ and October $18^{\text {th }}$.

In 2019 the first pollen grains of goosefoot were observed in the air of in Hungary, in Kaposvar on June $7^{\text {th }}$, then one day later than in Hungary, pollen season started in Slovakia, in Žilina. In Poland the pollen season started in Opole and Szczecin on June $14^{\text {th }}$. The Chenopodiaceae pollen season lasted the longest in Slovakia until October $16^{\text {th }}$. The differences of pollen season durations were considerable, from 72 to 128 days.

As the family Chenopodiaceae is represented by many taxa, the pollen seasons are long with many peaks and low SPI values [12, 13]. In 2019, in this study the dynamics of the pollen seasons of goosefoot family show similarities within a given country and 
considerable differences between individual countries (fig. 1-9). In Poland, pollen concentration values are low and their inconsiderable increase occurs at the be- ginning of August. Maximum seasonal values in Polish cities are observed at different times, from July $26^{\text {th }}$ to August $29^{\text {th }}$ (tab. 1). In Hungary, on August $9^{\text {th }} / 10^{\text {th }}$,

Figure 1. Goosefoot pollen count in Bialystok, Bydgoszcz and Cracow (Poland) in 2019.

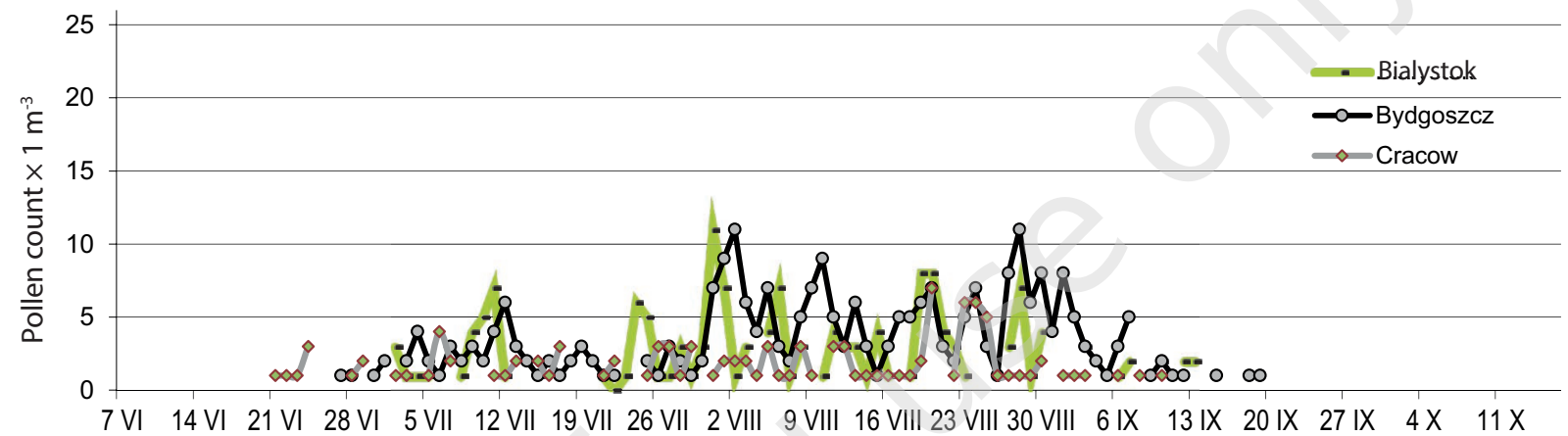

Figure 2. Goosefoot pollen count in Sosnowiec, Lublin and Olsztyn (Poland) in 2019.

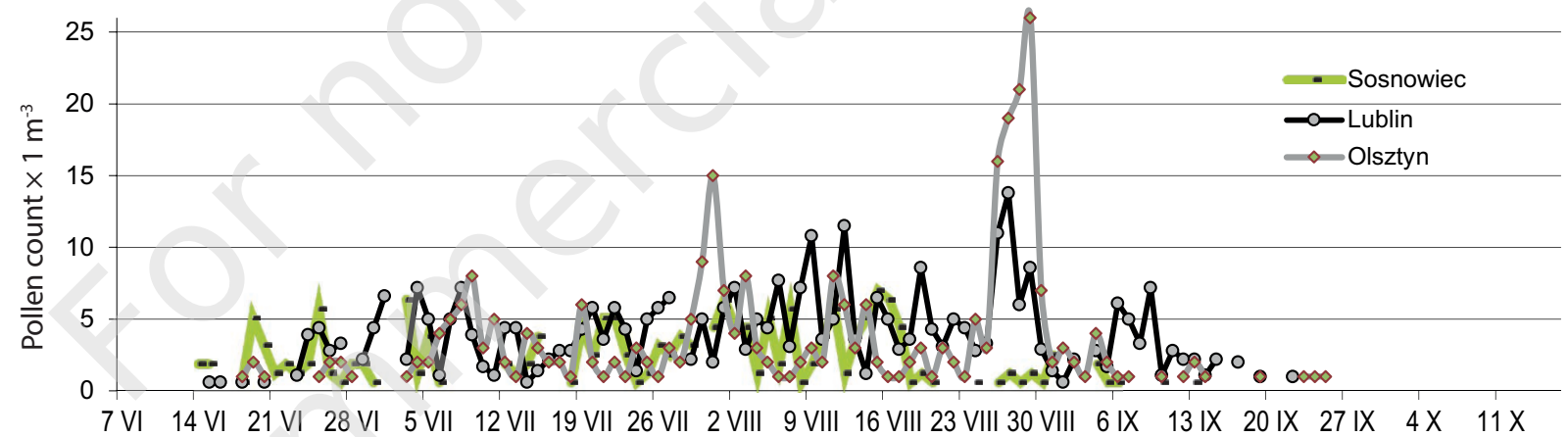

Figure 3. Goosefoot pollen count in Opole, Piotrkow Trybunalski and Szczecin (Poland) in 2019.

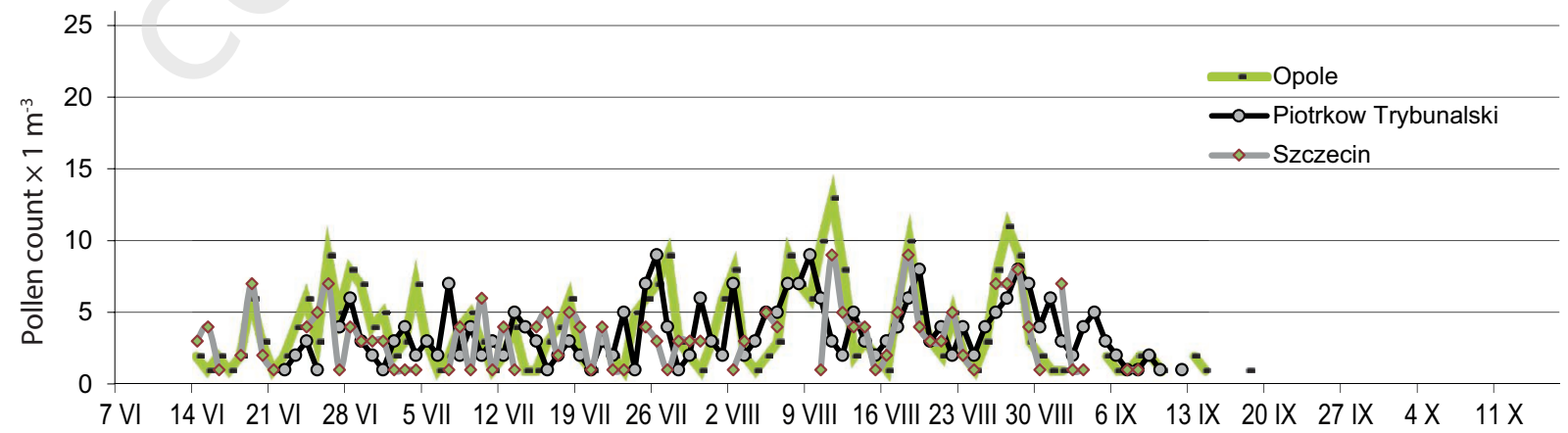

Figure 4. Goosefoot pollen count in Warsaw, Wroclaw and Zielona Gora (Poland) in 2019.

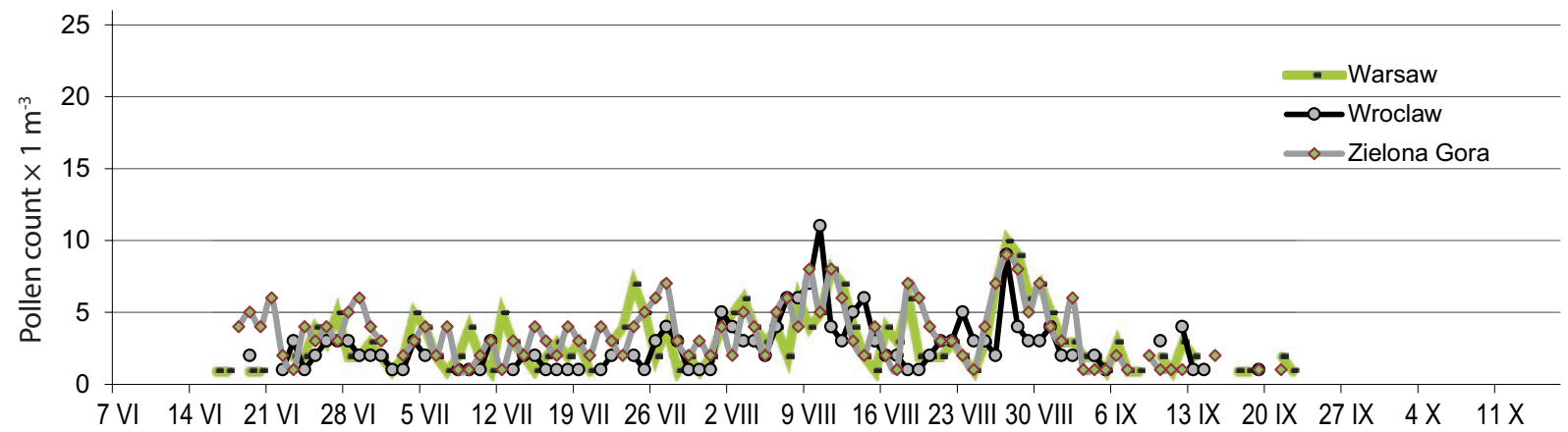


Figure 5. Goosefoot pollen count in Budapest, Debrecen and Gyor (Hungary) in 2019.

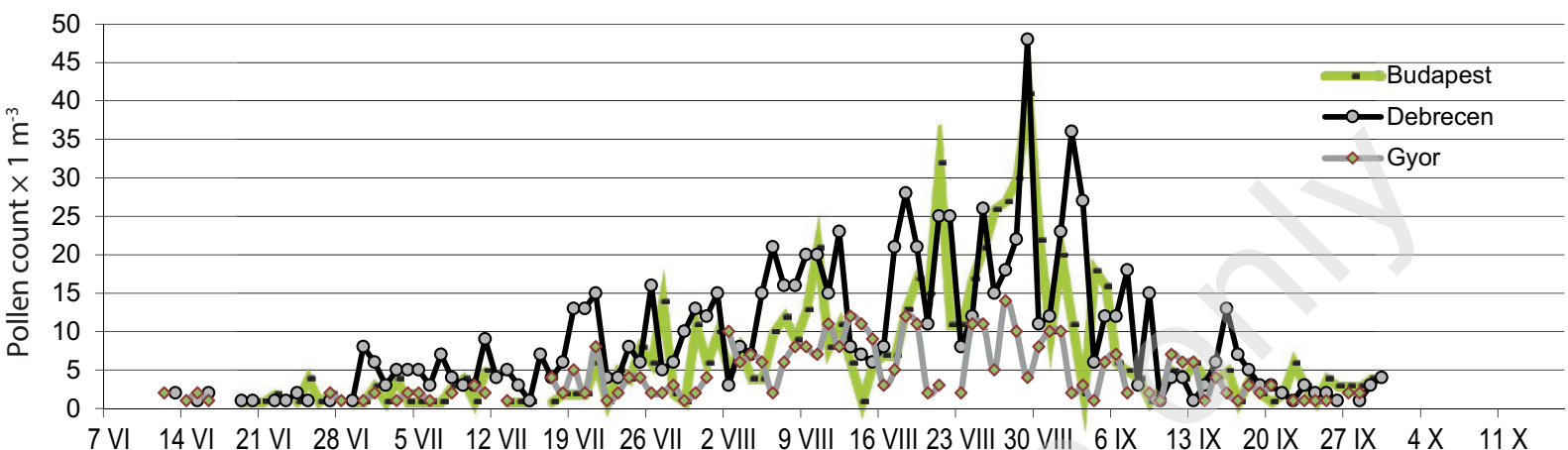

Figure 6. Goosefoot pollen count in Kaposvar, Kecskemét and Miskolc (Hungary) in 2019.

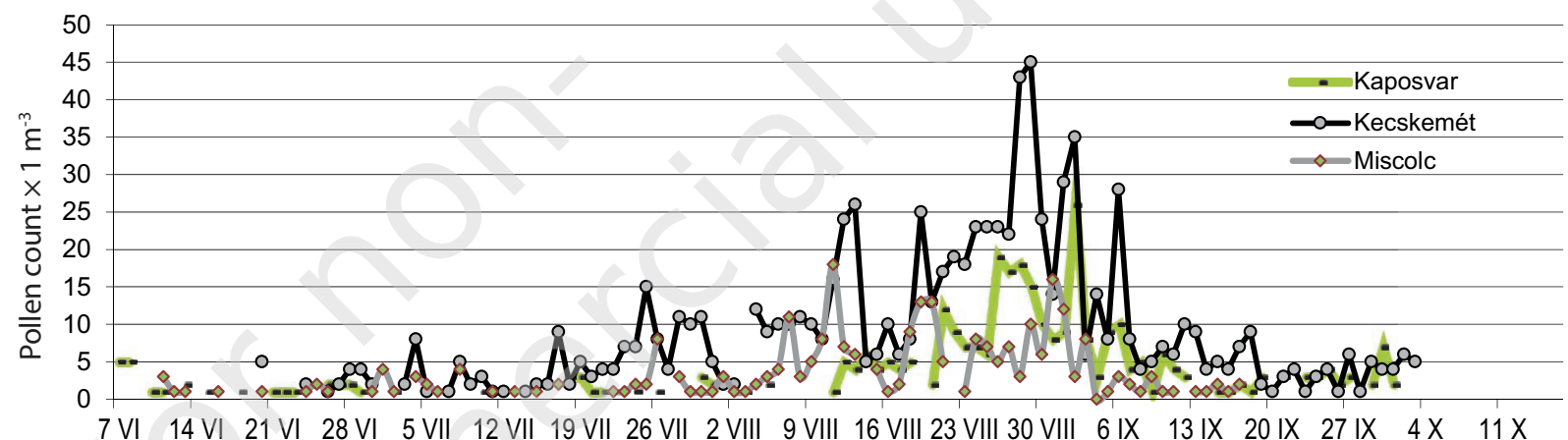

Figure 7. Goosefoot pollen count in Nyíregyháza, Pecs and Siofok (Hungary) in 2019.

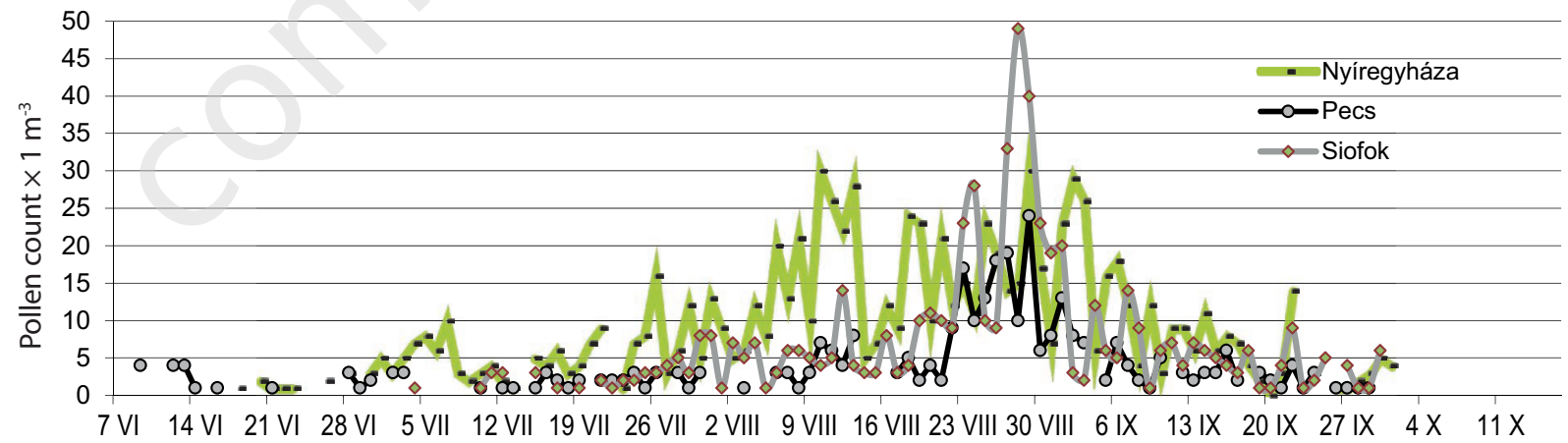

Figure 8. Goosefoot pollen count in Bratislava, Banská Bystrica and Nitra (Slovakia) in 2019.

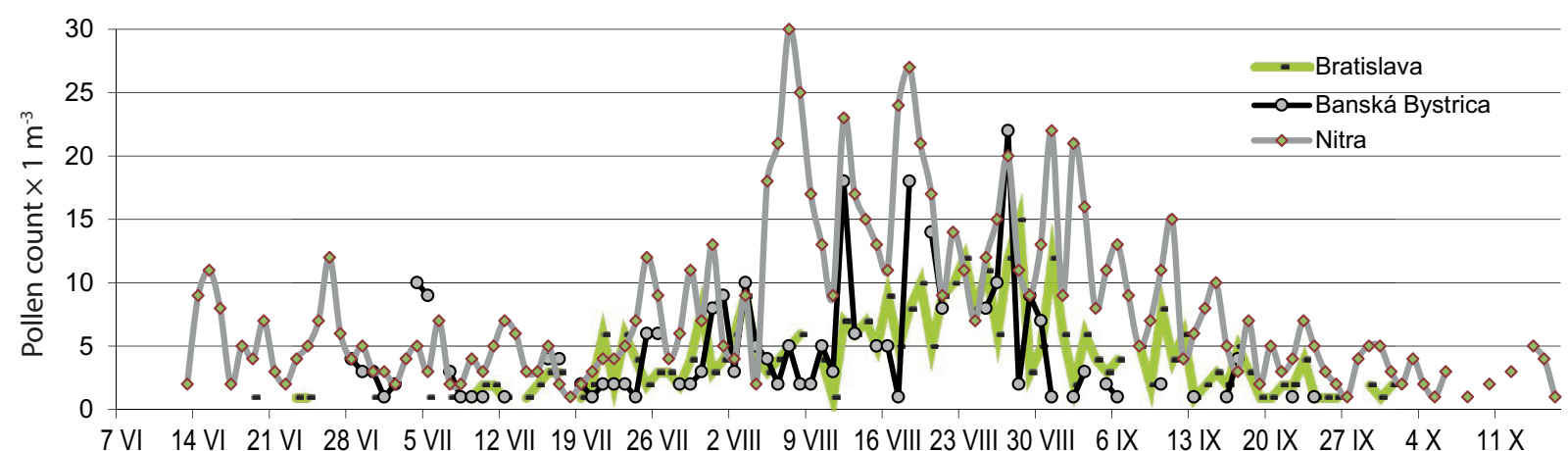


Figure 9. Goosefoot pollen count in Trnava and Žilina (Slovakia) in 2019.

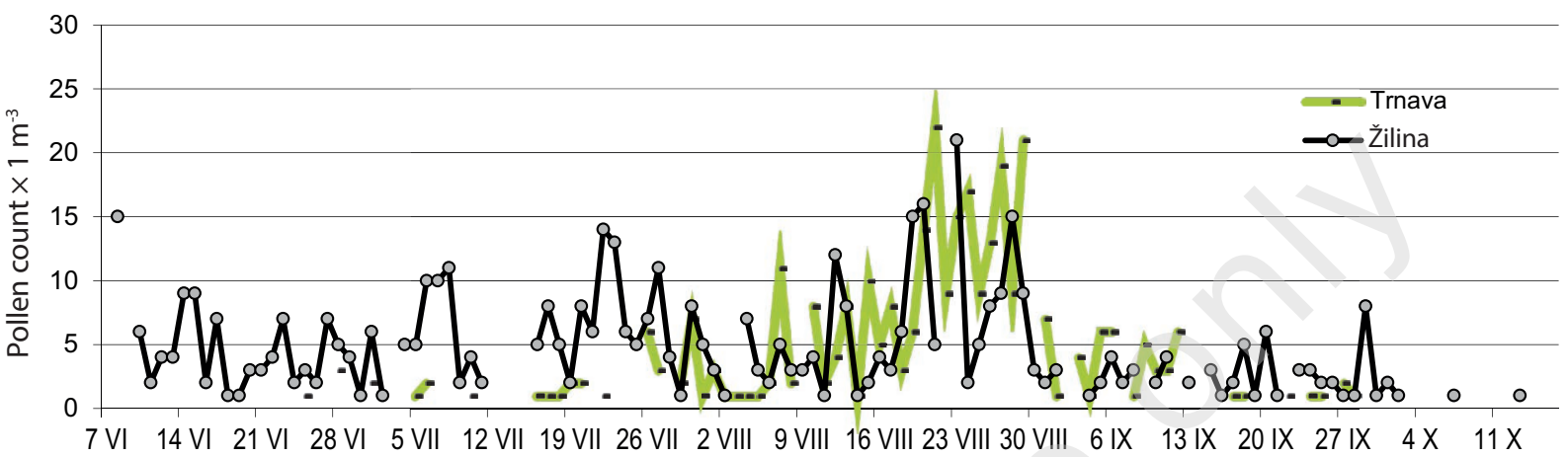

a marked increase in pollen concentrations is observed. Peaks above 20 grains $/ \mathrm{m}^{3}$ in most Hungarian cities occur almost at the same time, from the $27^{\text {th }}$ to August $30^{\text {th }}$ (tab. 2). In Slovakia, the increase in the concentration of goosefoot pollen is recorded at the end of August and is higher than in Poland and lower than in Hungary (tab. 3). The maximum values of pollen concentrations in Slovakia occur between $7^{\text {th }}$ and $28^{\text {th }}$ of August, which is similar to Poland.

Maximum concentration of goosefoot pollen described in Poland by Malkiewicz et al. [11] in 2018 was varied, it fluctuating between 7 grains $/ \mathrm{m}^{3}$ in Cracow and 26 grains $/ \mathrm{m}^{3}$ in Bialystok. Highest concentrations in given cities in Poland were noticed in 2018 in August (between $4^{\text {th }}$ and $21^{\text {st }}$ ).

Chenopodiaceae pollen has been found in the atmosphere of Cordoba, Spain, virtually throughout the whole year, although its presence was continual only between April and October, with maximum concentrations detected in the summer months. Of 1,000 patients, over $8 \%$ were sensitised to this pollen [14].

The highest goosefoot pollen allergen hazard occurred in 2019 undoubtedly in Hungary: in Debrecen, Kecskemét, and Nyíregyháza (tab. 2). Much less risk occurred in Slovakia; in Poland the risk was very low at all measuring points. The highest variability in the analysed seasons was found in the peak value and annual total. The lowest diversity concerned the length of the pollen season.

European studies have reported the significance of goosefoot pollen. Sites included Greece and Poland, where examination of the records of 8,576 patients with "upper airway" allergy documented hypersensitivity to weed pollen allergens in $12.5 \%$, the most prevalent sensitisation being to wormwood $(86.2 \%)$, mugwort $(82.9 \%)$, and white goosefoot $(44.3 \%)$ [15]. Also Chenopodiaceae pollen has been reported to cause allergy in desert countries where it is well adapted. A significant feature of goosefoot family sensitivity is its concomitant appearance with other pollinoses and probably explains the little attention that this allergy has received [16]. Rodriguez-Rajo et al. [17] announced an allergenic significant value for Chenopodiaceae pollen of 50 grains $/ \mathrm{m}^{3}$. In 2019, in none of the analysed cities of Poland, Hungary and Slovakia was this threshold value of pollen concentrations exceeded, which proves the low risk of goosefoots pollen allergens.

\section{Conclusions}

Goosefoot family pollen grains are present in the air of Polish, Hungarian and Slovak cities usually from mid-June until the end of September in Poland, however, in Hungary and Slovakia, until the beginning of October.

Chenopodiaceae pollen season in Poland lasted about 70-100 days; in Hungary - about 80-117 days; and in Slovakia - 90-130 days.

Pollen season was characterized by extremely different total annual pollen SPI, in Poland from 116 to 360; in Hungary and Slovakia within the limits 290 to 980 .

The highest goosefoot pollen allergen hazard occurred in 2019 mainly in Hungary and Slovakia. The number of days with concentrations above the 20 grains $/ \mathrm{m}^{3}$ was very different: over 12 days in high season in Debrecen, Kecskemét and Nyíregyháza (Hungary), even 10 days in Nitra (Slovakia) and only 2 days in Olsztyn (Poland). In other cities in Poland, there were no days with concentrations above 20 grains $/ \mathrm{m}^{3}$.

The dynamics of the pollen seasons of goosefoot family show similarities within a given country and considerable differences between individual countries. The highest variability in the analysed seasons 
was found between Poland, Hungary and Slovakia mainly in the peak value, annual total and exposure to pollen allergens.

Droughts that occur more frequently during the summer facilitate the spread of species of the Chenopodiaceae family due to the possibility of these plants gaining new habitats. As a consequence, the exposure to goosefoot pollen allergens in allergic patients may be increased, especially in hot, dry summers.

\section{References}

1. Stemeseder T, Hemmer W, Hawranek T et al. Marker allergens of weed pollen - basic considerations and diagnostic benefits in the clinical routine. Allergo J Int. 2014; 23(8): 274-80. https://doi.org/10.1007/s40629-014-0033-1.

2. Rapiejko P. Alergeny pytku komosy. Alergoprofil. 2009; 5(1): 42-3.

3. Compes E, Hernandez E, Quirce S et al. Hypersensitivity to black locust (Robinia pseudoacacia) pollen: "allergy mirages". Ann Allergy Asthma Immunol. 2006; 96(4): 586-92.

4. Monoszon MCh. Opredelitel pylcy widow semojestwa marewych. Izdatielstwo Nauka, Moskwa 1973.

5. Ralska-Jasiewiczowa $M$, Latałowa $M$, Wasylikowa $K$ et al (ed). Late Glacial and Holocene history of vegetation in Poland based on isopollen maps. Polish Academy of Sciences, Cracow 2004.

6. Huntley B, Birks HJB. An Atlas of past and present pollen maps of Europe: 0-13000 years ago. Cambridge University Press, Cambridge 1983.

7. Mandrioli P, Comtois P, Dominguez E et al. Sampling: Principles and Techniques. In: Mandrioli P, Comtois P, Levizzani V (ed). Methods in Aerobiology. Pitagora Editrice Bologna, Bologna 1998: 47-112.

8. Emberlin J, Savage M, Woodman R. Annual variations in the concentrations of Betula pollen in the London area 1961-1990. Grana 1993; 32: 359-63. https://doi. org/10.1080/00173139309428965.

9. Gehring R. The influence of the hot and dry summer 2003 on the pollen seasons in Switzerland. Aerobiologia 2006; 22: 27-34.

10. Puc M. Meteorological factors and pollen season dynamics of selected herbaceous plants in Szczecin, 2004-2008. Acta Agrobotanica. 2009; 62(2): 97-109.

11. Malkiewicz M, Chtopek K, Dabrowska-Zapart K et al. The goosefoot in the air of selected Polish cities in 2018. Alergoprofil. 2018; 14(4): 105-10.

12. Docampo S, Recio M, Trigo M. Risk of pollen allergy in Nerja (southern Spain): a pollen calendar. Aerobiologia. 2007; 23(3): 189-99.
13. Kasprzyk I. Sezonowe zmiany koncentracji ziaren pytku w powietrzu. In: Weryszko-Chmielewska E (ed). Aerobiologia. Wydawnictwo Akademii Rolniczej, Lublin 2007.

14. Galan C, Infante F, Ruiz de Clavijo E et al. Allergy to pollen grains from Amaranthaceae and Chenopodiaceae in Cordoba, Spain. Annual and daily variation of pollen concentration. Ann Allergy. 1989; 63(5): 435-8.

15. Gniazdowska B, Doroszewska G, Doroszewski W. [Hypersensitivity to weed pollen allergens in the region of Bygdoszcz]. Pneumonol Alergol Pol. 1993; 61(7-8): 367-72.

16. Lombardero $M$, Duffort $O$, Carreira J. Allergenic significance of chenopodpollen. In: D'Amato G, Spieksma FThM, Bonini $S(e d)$. Allergenic pollen an dpollinosis in Europe. Blackwell Scientific Publications, Oxford 1991: 128-31.

17. Rodriguez-Rajo FJ, Jato V, Aira MJ. Pollen content in the atmosphere of Lugo (NW Spain) with reference to meteorological factors (1999-2001). Aerobiologia. 2003; 19(3): 213-25.

ORCID

M. Puc - ID - http://orcid.org/0000-0001-6734-9352

P. Rapiejko - ID - http://orcid.org/0000-0003-3868-0294

D. Magyar - ID - http://orcid.org/0000-0001-8635-6451

J. Ščevková - ID - http://orcid.org/0000-0002-3432-4105

T. Wolski - ID - http://orcid.org/0000-0002-1368-6107

K. Piotrowska-Weryszko - ID - http://orcid.org/0000-0003-3827-3218

M. Malkiewicz - ID - http://orcid.org/0000-0001-6768-7968

G. Siergiejko - ID - http://orcid.org/0000-0003-4084-8332

E. Kalinowska - ID - http://orcid.org/0000-0003-4821-6882

K. Szczygielski - ID - http://orcid.org/0000-0003-3729-2679

A. Wieczorkiewicz - ID - http://orcid.org/0000-0003-1705-2264

A. Lipiec - ID - http://orcid.org/0000-0003-3037-2326

Authors' contributions:

Work input: A - work concept, B - aerobiological data, C - literature review, D - writing the thesis, $E$ - work correction.

Puc M.: A, B, C, D, E; Rapiejko P.: B, C; Magyar D.: B; Udvardy 0.: B; Ščevková J.: B; Lafférsová J: B; Wolski T: B; Piotrowska-Weryszko K: B; Malkiewicz M.: B: Siergiejko G: B; Dąbrowska-Zapart K.: B; Ziemianin M.: B; Kalinowska E.: B; Szczygielski K.: B; Wieczorkiewicz A.: B: Lipiec A.: B.

Conflict of interests: The authors declare that they have no competing interests.

Ethics: The contents presented in this paper are compatible with the rules the Declaration of Helsinki. EU directives and standardized requirements for medical journals.

Financial support: Research in Bialystok, Bydgoszcz, Olsztyn, Opole, Piotrkow Trybunalski, Warszawa, Wroclaw and Zielona Gora funded by Allergen Research Center Ltd.

Copyright: (C) Medical Education sp. z 0.0. This is an Open Access article distributed under the terms of the Attribution-NonCommercial 4.0 International (CC BY-NC 4.0). License (https://creativecommons.org/licenses/by-nc/4.0/), allowing third parties to copy and redistribute the material in any medium or format and to remix, transform, and build upon the material, provided the original work is properly cited and states its license.

Correspondence:

Malgorzata Puc, MD, PhD, Assoc. Prof. Institute of Marine \& Environmental Sciences, University of Szczecin, Poland 71-412 Szczecin, Z. Felczaka 3c e-mail: malgorzata.puc@usz.edu.pl 